\title{
Why Comparing Experiences with Democracy in Latin America Matters
}

Pablo Calderón Martínez*

Sergio Aguayo Quezada, La Vuelta en U: Guía para Entender la Democracia Estancada (Mexico City: Taurus, Santillana Ediciones Generales, 2010).

Manuel Alcántara Sáez, El Oficio del Político (Madrid: Editorial Tecnos, 2012).

Ana María Bejarano, Precarious Democracies: Understanding Regime Stability and Change in Colombia and Venezuela (Notre Dame, IN: University of Notre Dame Press, 2011).

Reynaldo Yunuen Ortega Ortiz, Movilización y Democracia: España y México (Mexico City: El Colegio de México, 2008).

Andrew Selee and Jacqueline Peschard (eds), Mexico's Democratic Challenges: Politics, Government, and Society (Palo Alto, CA: Stanford University Press, 2010).

The view that democracy is the preferred form for government for most people is hardly ever contested. In a recent work, Francis Fukuyama (2011: 11) conveys this common sentiment when he unequivocally claims that 'most people around the world would strongly prefer to live in a society in which their government was accountable and effective'. Even if we were cautiously to share Fukuyama's optimism - bearing in mind, of course, that he is no stranger to controversy, and that nor has he ever shown much caution when putting forward grandiose statements - and believe that an 'accountable and effective' government (that is, a democratic one) is a common goal, there would still be much to be said about the multiple controversies surrounding the concept and the practice of democracy. If we were to ignore that there are probably as many definitions of democracy as scholars willing to write about it, and if we then accepted Fukuyama's premise that democracy is a common goal, then one

\footnotetext{
* Pablo Calderón Martínez is a PhD candidate in Spanish, Portuguese and Latin American Studies and tutor in Comparative Politics at King's College London. Contact email: pablo.calderon_martinez@kcl.ac.uk.
} 
would have to ask why it is that democracy is not the only form of government around the world. Comparative politics has tried to address this apparently straightforward question from a variety of perspectives; any number of variables ranging from institutional arrangements to cultural/religious traits have been proposed as the underlying causes for the failure of some countries to find a democratic solution to the problem of government. Although the paradoxes of democratization are not unique to Latin America, this is a region that has hovered between full-on authoritarianism and important democratic advances, and it now seems, for the most part, to be caught somewhere in between - in a perennial state of democratization. ${ }^{1}$

Of the many Latin American cases that seem to challenge the initial, and more frequently referenced, ${ }^{2}$ theories on democratization it is probably the cases of Mexico, Venezuela and Colombia that stand out as the most problematic. Mexico is unique in that it seems to have been on the brink of full democratization since the leaders of the 1910 revolution decided to put aside their differences and operate within the confines of a heavily institutionalized party. However, despite international and domestic scholars placing the Mexico of the 1960s loosely among the democratic world, ${ }^{3}$ the Institutional Revolutionary Party (Partido Revolucionario Institucional, PRI) regime failed to deliver what seemed to be the imminent arrival of democracy during the more than 70 years that the party held onto near-absolute power. What is more problematic is that the electoral victories gained by the opposition since the 1980 s and the two consecutive presidencies under the National Action Party (Partido Acción Nacional, PAN) have not done much to change the view that Mexico's supposedly unstoppable path towards democracy is once again, as Aguayo Quezada (2010) suggests, stagnated. In a different vein, both Venezuela and Colombia stand out as the two countries that have suffered the worst democratic regressions in the region. At first glance, it seems the pendulum analogy used in Precarious Democracies (Bejarano 2011: 12) to describe the oscillation between democracy and authoritarianism in Latin America is of particular relevance when describing recent political changes in both countries; it appears that two of the most successful democracies in the region are feeling the inevitable gravitational pull of Latin America's doomed destiny and are being propelled with vehement acceleration towards authoritarianism.

These three cases can also work as a testing ground for many of the different theories that try to explain democratization. It is somewhat puzzling that Latin America has been 
portrayed as being immersed in a unified pendulum pattern simply because of geographical and historical considerations. The idea that cultural and/or structural elements can have a determining factor in a country's (or a whole region's) political developments no longer holds the sway it once did. Despite current setbacks, the success of Southern and Eastern European democratizations proved that democracy is not suited only for Protestant societies, just as the laudable efforts to democratize the Arab world from within have proven that democratization does not have to mean 'Westernization'. It is therefore necessary to avoid the assumption that there is a single sequence of events (or variables) that explain the failure to consolidate democratic regimes around Latin America. This is a point expertly and elegantly developed in the opening pages of Ana María Bejarano's Precarious Democracies (2011), where the author draws on Tolstoy's famous novel to develop the 'Anna Karenina principle':

Like many other complex social phenomena, democracy is a multifaceted proposition: in order to build and sustain a democratic regime, a society needs to meet a bundle of conditions. The absence of one of them can throw the complex artefact into disarray, thus making for regimes that fail to achieve the basic characteristics of a well-established, functioning democracy. Success, indeed, requires avoiding many causes of failure. Thus, to paraphrase Tolstoy, while all happy democracies are alike, each unhappy democracy is unhappy in its own way. (Bejarano 2011: 3)

If this holds true for two cases (Colombia and Venezuela) that appear to have struggled to deal with almost identical challenges, it would be safe to assume that it holds true for other Latin American countries. In any case, even though Bejarano's main goal of further discrediting an already discredited theory (that transitions achieved by elite bargaining and pacts are more successful) seems a bit muted, this is not to the detriment of what is a very good example of how small-N studies are necessary to identify the limits of any theory that tries to come up with a magic bullet explanation for democratization. Conversely, Bejarano's criticism of the classic structural explanation that Venezuelan and Colombian political regimes developed at different speeds because of their main exports - Venezuela's oil-based economy led to a rapid industrialization, whilst Colombia's coffee-based economy made state consolidation harder - is a perfectly valid one. Yet, as with her criticism of the hypothesis that sees democratization as an elite-driven process, she is hardly the first person to find holes in modernization theory. In short, the contribution to the theory - albeit perfectly valid and 
well developed - is not quite as significant as the analysis of the institutional progressions in both countries that has led to the precarious situation of their respective democracies.

Indeed when reading Precarious Democracies (Bejarano 2011), one does not get the impression that this is a book that attempts to develop a single theory that explains democratization nor that it is one that tries to explain why democratic regimes have proven less than a success elsewhere in the region. This is a work that paints a fair picture of the many challenges democracy has to overcome in a region besieged by inequality: a complicated history characterized in many cases by a clear cultural continuity yet marked by political breaks, ${ }^{4}$ a particularly corrupt political elite - which, in an overzealous attempt to play down the role of agency, Bejarano almost completely ignores - and the ever-looming presence of the northern hegemon. Indeed, by analysing the historical evolution of the political institutions that have constrained the political developments in Colombia and Venezuela, Precarious Democracies avoids following the common - not to mention misleading - trend followed by some Latin American authors of presenting opinions as facts and engaging in blatant proselytizing. In a time when the study of political parties remains as relevant as ever for Latin American scholars, Bejarano's analysis of the evolution of political parties in both countries, the role these played in shaping politics and society, as well as the very nature of the pacts opposing elites agreed upon (who was included and excluded from these pacts, what role the military played and how much room for manoeuvre the pacts allowed) stands above the rest. The use of historical institutionalism does allow for a reinterpretation of Colombia's and Venezuela's democratic challenges that is not based solely on poorly developed arguments, such as the above-mentioned structural explanations or the tendency to label both cases as 'pacted transitions'. It also allows for a study of Colombia's political development that is not focused on the failure of the state to contain violent challengers - although not ignoring it either - and, even more refreshingly, it presents an explanation for Venezuela's extraordinary democratic collapse that is not dominated by the personality of Hugo Chávez.

Can political parties, pacts and historical institutionalism explain why democracy has failed to become the 'only game in town' in other Latin American countries? The importance of political parties varies considerably from case to case. Cases such as Colombia's Conservative and Liberal parties, Uruguay's Colorado Party (Partido Colorado) and Mexico's Institutional Revolutionary Party are clear examples of political parties playing leading roles 
in state-building and political development (in Colombia the traditional political parties have dominated political development almost since independence). There is no disagreeing with the notion that when political parties achieve a high degree of institutionalization and participation they become integral parts in the development of any regime, not just democracies. However, there is a very real risk that by trying to explain why certain political parties emerge and why some are more successful in institutionalizing than others, we end up by concluding that it is all down to structural, cultural or elite cleavages after all, hence returning to what we were trying to discredit. In some other cases, such as post-revolutionary Mexico, elites agree pacts in what can truly be described as an institutional vacuum where there are no tangible structural limitations. The only institutional restraint Plutarco Elias Calles had when carefully orchestrating the pacts that were to give birth to the earlier predecessor of the Institutional Revolutionary Party was the weak and contradictory 1917 Constitution (still active to this day); it is effectively a socialist and democratic constitution ratified by a government (led by Venustiano Carranza) that was neither democratic nor socialist. The reality is that there was not a single political institution that survived the revolution, and most of the elites that profited from the Porfiriato were either killed, expelled or joined the revolution. This allowed the different caudillos to engage in free-for-all negotiations without being limited by institutions or without having to worry about any sort of popular support other than their loyal troops (usually from their respective home states or regions). In this case it is impossible to distinguish between the party's and the state's development, just as it is impossible to ignore the pivotal role of agency in the whole process.

The case of Mexico evidences that historical institutionalism and structural considerations can only explain so much. This is not to say that to understand Mexico's democratic development we have to concentrate exclusively on elite bargaining. The fact that Mexico's institutional development is diametrically different to that of Colombia or Venezuela reinforces Bejarano's Anna Karenina principle: Mexico - from the perspective of historical institutionalism - must be an unhappy democracy for different reasons to those of Colombia and Venezuela. In Movilización y Democracia, Reynaldo Yunuen Ortega Ortiz (2008) shares Bejarano's contempt for elite theory without neglecting the part that pacts play in securing regime change. Aguayo Quezada (2010: 24) goes even further: he not only refuses to accept elite theory as an explanation for political change but he also accuses the main proponents of elite theory (Juan Jose Linz, Guillermo O'Donnell and Philippe Schmitter) of justifying the Institutional Revolutionary Party regime in the eyes of the 
international community, thus enabling the regime to survive longer. I am not sure there are many scholars who would actually believe that the international community is duly waiting for their approval before they take a stance against an undemocratic regime. Personally, I am not about to buy into the argument that Linz, O'Donnell and Schmitter were being purposely disingenuous, as Aguayo Quezada hints (2010: 24), ${ }^{5}$ when they struggled to categorize the Institutional Revolutionary Party regime as outright authoritarian.

In any case, with the probable exception of Alcántara Sáez's monograph (2012), all of the works under review here agree with the notion that elites have not been at the fore of democratic advances in the region. Although there seems to be an agreement that elites have not been the driving force behind democratic trends in the countries under analysis - actually the opposite has been the case - and, more often than not, there is no consensus (nor should there be) on what it is that explains democratic developments in the region. Institutional explanations certainly seem to be favoured over structuralism or agency, yet there is no one form of institutionalism. Movilización y Democracia (Ortega Ortiz 2008: 30-5) shares Bejarano's idea, based on Barrington Moore's work (1966) that socioeconomic development presents a structure that confines the actions of the participants (that is, structuralism), and that political parties are bridges that translate the interests of societal groups - brought about from the conflict inherent in economic development - into demands to the political elites. The difference between Bejarano and Ortega Ortiz is that the latter focuses his analysis on the emergence of opposition parties and social movements rather than on the nature of the pacts that serve as the basis for democratic development. This broadly helps explain why Ortega Ortiz compares Spain and Mexico instead of using a similar system design; what explains the difference in the outcome, according to Ortega Ortiz, is the degree of institutionalization of the authoritarian regime and the ability of opposition parties duly to channel societal aspirations.

Movilización y Democracia (Ortega Ortiz 2008), as the title suggests, is more concerned with social movements than with pacts. Although the vast majority of the extensive literature on the Spanish transition has focused almost exclusively on elite pacts, ${ }^{6}$ there are important works that have broken with this model in the past: Laura Desfor Eldes (1995) and Omar Encarnación (2001) stand out as proponents of bottom-up interpretations of the Spanish path to democracy. Yet Ortega Ortiz's institutionalist interpretation of developments in Spain from the 1950s up until the transition to democracy is in itself rather 
original. The argument that the main explanatory factor for the transition 'is not the existence of moderate groups inside the elites but rather the continuous process of social mobilization in favour of democracy that limited the choices available to those elites' (Ortega Ortiz 2008: 129) puts him at odds with the majority of the literature on the Spanish transition. The role Ortega Ortiz gives to political parties, trade unions and student groups as organizations capable of channelling societal demands is what makes his analysis fit the traditional model of institutionalism; it is one that is not often associated with the Spanish transition. He thus incorporates the Iberian case into a Latin American rhetoric dominated by institutionalism and civil society/social capital explanations.

It is no accident, however, that the Spanish transition has become such a paradigmatic case, not only for elite and pact theorists but also for proponents of alternative views on democratization. What made the transition to democracy in Spain fit the elite/pact model is that, probably unlike any of the Latin American transitions to and from democracy, the groups within the elites - moderates vs. 'the bunker' - as well as the elites themselves continuistas vs. rupturistas - were relatively easy to identify. Similarly, the institutions (political parties, unions and other groups) that took part in the transition were recognized as independent actors. The problem with Movilización y Democracia (Ortega Ortiz 2008) is that Spain's and Mexico's respective social and political development have just been too different. The role that civil society and opposition parties have played, or are still playing, in Mexico's democratization is well documented. Mauricio Merino's description (2003) of the Mexican struggle for democracy as a 'voted transition' explains how opposition parties focused exclusively on democratic gains in the electoral arena and neglected to support democracy from below - a point echoed by Aguayo Quezada (2010). In her chapter in Mexico's Democratic Challenges, however, Mariclaire Acosta (2010: 274) - the Director of Freedom House Mexico - explains how, despite believing it, civil society in Mexico was not setting the beat to the transition but rather setting the chorus. This reality shaped the transition process as well as the institutional arrangements in the country. In short, despite the author's best efforts, Movilización y Democracia (Ortega Ortiz 2008) fails to identify the discrepancies that led to the different degrees of success in the two transitions. The impressive analysis of the institutional and civil society developments, as well as the interactions between them, found in this work does not translate into a convincing explanation for the difference in outcomes: the Spanish transition was more successful because its civil society was better organized, the authoritarian regime was less 
institutionalized, opposition parties were more effective in transforming societal demands into political action, the respective elites acted more responsibly and the democratic forces had more international support, especially the Spanish Socialist Workers' Party, than the Mexican actors challenging the Institutional Revolutionary Party regime ever had. This is the Anna Karenina principle taken to the extreme: two completely different families being completely different for completely different reasons.

What is indeed refreshingly distinctive about Ortega Ortiz's work is his commitment to political objectivity - something rarely found in a country where academic and political careers go hand in hand. Jumping from academia to politics and then back to academia (or from politics to academia, back to politics and ending up in academia, or from academia to politics, and so on), although not a practice exclusive to Mexican academics, is an uncomfortably common occurrence. In a country suffering the hangover of over 70 years of the 'perfect dictatorship' - as it was famously described by Mario Vargas Llosa (El País 1/9/1990) - the line between serious academic work and political propaganda has not always been clear. As with almost every other organization and/or sector, the Institutional Revolutionary Party used its highly vertical structure and control over resources effectively to regulate academic output. It is no coincidence that former presidents Miguel de la Madrid and Ernesto Zedillo, for example, were awarded federal scholarships to pursue postgraduate studies at Harvard and Yale, respectively, shortly after officially joining the Institutional Revolutionary Party. The system of selective rewards essentially worked as a self-censoring mechanism for the Mexican 'intelligentsia'. Spearheaded by Octavio Paz, Mexican intellectuals would rarely engage in criticism towards the regime and whenever they did they were immediately discredited by the regime's huge propaganda machine. This less than ideal relationship was not helped when, probably in an attempt to improve his image as a likable but not very intelligent character, Vicente Fox surrounded himself with a number of selfproclaimed left-wing academics, including Jorge Castañeda, Adolfo Aguilar Zinser and Sergio Aguayo Quezada. As Aguayo Quezada himself relates in La Vuelta en $U$ (2010), this was a marriage that was not meant to last. Despite his impressive resistance to US pressure to sanction the war in Iraq, Aguilar Zinser was removed from his post as United Nations Security Council ambassador when he had the temerity to consider the possibility that the US still regarded Mexico as its 'back yard'; Castañeda lasted a little over two years as secretary of foreign affairs, and Aguayo Quezada, apparently, was disillusioned by Fox's refusal to commit to the findings of his Truth Commission. Whether it was the academics who deserted 
Fox or if it was the former president who became disillusioned with their proposals we will never know for sure. What is evident, though, is that Fox-bashing has become a sort of obsession in certain Mexican academic and intellectual circles.

Aguayo Quezada's harsh judgment of Fox, for example, is justified by the clear failure of Fox's government to deliver on many of his main mandates, especially that of securing the reforms needed to advance democracy, but his clear animosity towards Fox takes him to develop a rather one-sided analysis of the 2006 contested elections. He blames everyone from Fox to the business class - who, unsurprisingly, decided to put their weight behind the centre-right candidate rather than the leftist candidate Andrés Manuel López Obrador - to the Europeans' 'pragmatism' (Aguayo Quezada 2010: 203) for the defeat of the left in the 2006 elections. Although he presents a thorough and instructive analysis of the post-electoral political crisis, his obsession with discrediting the National Action Party causes him to deviate from what was, in my opinion, and that of Jean-François Prud'homme (2010: 53), the core reason for the crisis: the electoral authorities had to act within the laws and institutions approved by all the main political parties. Despite all the Fox-bashing, the many deficiencies of his government, and his ill-judged influence in the electoral process, the fact remains that 'up until the 2006 elections, no political party embraced electoral reform as a key issue or denounced electoral law, because most of them believed that the prevailing conditions still favoured them' (Prud'homme 2010: 53).

At the end of it all, Aguayo Quezada (2010) offers an interpretation of Mexico's democracy that is closer to the current zeitgeist: Mexico needs a comprehensive institutional reform that will only be achieved when civil society organizes itself and demands this from the political elite that has lost touch. His final analysis (which he calls a 'guide to reactivate democracy'), although not entirely innovative, does paint a general picture of what is wrong with Mexican democracy. However, Aguayo Quezada (2010: 278) presents an unfair characterization of Mexico - and by inference Mexicans - as a 'misogynist, authoritarian and racist' country that leaves little room for optimism; this is an understandable view that is shared by many Mexican scholars who seem disenchanted with the transition. This view, though, is not common among observers from abroad. Despite being published in the same year as La Vuelta en U (Aguayo Quezada 2010), the introductory chapter to Mexico's Democratic Challenges by Andrew Selle and Jacqueline Peschard (2010) shares many of the concerns put forward by Aguayo Quezada but presents a much more positive view of 
Mexican society and the prospects for democracy in Mexico. The authors believe that 'even with its difficulties, the beginning of real competition among political parties that have roots in society suggests an important step forward of Mexican democracy' (Selee and Peschard 2010: 19). The return of the Institutional Revolutionary Party to the presidency will certainly test anyone's optimism, but - at least until the re-emergence of the old party became an imminent reality in the last two years - international commentators tended to be more positive about Mexico's prospects for democracy. Both Chappell Lawson and Jorge I. Domínguez, two of the most respected scholars in current Mexican politics in the US, give a far more positive account of the 2006 electoral crisis and its consequences than the one presented by Aguayo. ${ }^{7}$

It is somewhat ironic that, as someone who condemns elitist interpretations of democratization, Aguayo Quezada spends so much time and effort discrediting a single political leader. His suggestions for reactivating Mexican democracy from below are not, in my opinion, as noteworthy as his impressive analysis of the emergence of 'de facto powers' after the decline of a highly centralized state. This has been a significant theme for students of democracy in Latin America and a major source of disagreement among them. Bejarano (2011: 212-13) argues that the fragmentation of political parties in the region as well as a decline in their resources has allowed for other powers to emerge; this is certainly a pattern not unique to Colombia and Venezuela but also similar to the decline of the Institutional Revolutionary Party in Mexico. The emergence of real federalism in Mexico can be traced directly to the process of the Institutional Revolutionary Party's demise; Tonatiuh Guillén López (2010) and Jacqueline Peschard's (2010) chapters from Mexico's Democratic Challenges describe a process of rapid decentralization very similar to that presented in $L a$ Vuelta en U (Aguayo Quezada 2010). Everybody seems to agree that federalism emerged as the Institutional Revolutionary Party declined, but there are fundamental disagreements on what this has meant for the democratic process. Peschard (2010) has a slightly more positive view on decentralization than the ever pessimist Aguayo Quezada; in her view, state and municipal levels of government have presented opportunities for democratic advancements unlike the stagnation experienced at federal level - as well as regressions; in some cases governors have become true feudal lords. Guillén López (2010) also focuses on the positive influence of federalism. 
More recent works - such as the journalistic account presented by Jo Tuckman (2012) - paint a rather bleak picture of federalism as an endless source of authoritarian tendencies. The first reaction to an authoritarian party losing control of certain states is always positive: how could it not be good for democracy that the Institutional Revolutionary Party was losing control over great chunks of territory? The answer is simple: opposition parties may have wanted to end the Institutional Revolutionary Party's absolute control but they were not necessarily against absolute control. As Tuckman (2012: 91) correctly explains, 'whatever party they belong to, the new generation of feudal-style governors has not only helped limit democratization in particular states, but has also impeded negotiation of national policy'. A similar pattern was followed in Venezuela, where less than democratic forces took advantage of the decline in power of the traditional parties to seize whatever power they could. The loss of power and influence by one authoritarian group does not guarantee that this power will end up in pro-democratic forces, not even in a context of a transition to democracy. The likelier explanation is that decentralization of power in itself is not enough to advance democratization; just as elite pacts and institutional design, it all depends on how it is done.

The reasoning behind Manuel Alcántara Sáez's El Oficio del Político (2012) is harder to identify; his study of Latin American politicians as individuals has certainly been a sales success in Spain, but it fails to explain much about the political situation in the region. This is not a volume that deals with democratization as such, which invariably puts it at odds with the other works under review, but it is a study that should, by its own admission, lead to a debate over the role that 'parliamentarian elites' play in a democracy (Alcántara Sáez 2012: 15). This work, based on a significant amount of data stemming from impressive survey work in Latin America, is worthy of analysis simply because it breaks with the current trend in Latin American studies and looks at political elites as explanatory agents of change and/or continuity. Sadly, however, it offers little else to the study of democracy in the region. Alcántara Sáez's efforts to present this work as not entirely academic sound hollow - and more like an excuse to hide its clear deficiencies - when we consider that the whole volume is based on a broad quantitative research exercise clearly meant for rigorous academic work. It therefore feels contradictory that Alcántara Sáez, having spent years collecting a large amount of data, decided to put together a volume that combines conjectures and reflections with strong quantitative data. This may be because of the audience the book is aimed at, but it still has to be questioned. In either case, this volume feels more like a step back to the times of obsession with agency rather than a reinterpretation of the theory that incorporates the old 
and the new. Still, El Oficio del Político is an important reminder that people matter and, at least in Latin America, politicians matter even more.

The flow of scholarly literature on democracy and democratization has barely waned despite the supposed challenges it now faces. Even before the 'Arab Spring' revitalized the interest in democratization, and democracy promotion/building in particular, among policymakers and the general public, scholars have, from their different schools of thought, continued to push forward with the question of how democracy happens. It is a question that has never stopped tantalizing observers of Latin American politics; this is a region that, unlike any other, has toyed with authoritarianism and democracy and has settled for neither. As the works under review demonstrate, there is still a desire from the scholarly community to support the improvement of democracy in the region. Whatever the inclinations of the studies, they all aim to present alternative explanations to democratic developments in the region. The use of different types of institutionalism in Precarious Democracies (Bejarano 2011) and Movilización y Democracia (Ortega Ortiz 2008) probably place these two volumes more in tune with the perspectives currently dominating democratic theory but this does not mean that they lack originality. Both these works present detailed analyses of specific cases relevant to Latin America and they do so by using the frequently neglected tool of small-N comparisons. ${ }^{8}$ More importantly, though, they both contribute towards furthering Latin American studies that - without falling into stereotypical views that there is one answer to the Latin American question - explain the intricacies of the region. The same could be said about La Vuelta en U (Aguayo Quezáda 2010). Although developed within a less structured theoretical framework, Aguayo Quezada does present a very useful analysis of the peculiarities of the Mexican case and specific actions (or recommendations, as he calls them) to improve democracy in the country. As an edited volume, Mexico's Democratic Challenges (Selee and Peschard 2010) offers a more detailed view of the specific challenges that Mexico faces in its struggle for democracy far more expertly than any monograph ever could. The detail with which the Mexican case is analysed in this volume is nicely complemented by the variety of explanations given for Mexico's democratic struggles. In the closing remarks for the volume, Jesús Silva-Herzog Márquez (2010) floats the idea that maybe Mexico is not the only culprit in its democratic failure; perhaps democracy itself is the problem. In the same volume, John M. Ackerman (2010) identifies the Zapatista movement and other opposition pressures at the core of the transition but blames the failure to secure democratic advancements on the political elites and institutions; Alejandro Moreno (2010) challenges 
this view in his chapter in the same volume, and questions if Mexicans are more 'democratic' than before and, if they are, he doubts that this attitudinal change is at the fore of Mexico's democratic development. In short, a single edited volume analyses the democratic challenges of a single country from any number of different perspectives and proposes different actions to tackle them.

After the unprecedented amount of literature on Latin America that emerged during the so-called 'third wave', there finally seems to be a new paradigm emerging. The region is being used less and less as a testing-ground for different democratization theories and more single-case and small-N studies are emerging; grand volumes on Latin America such as $E l$ Oficio del Politico (Alcántara Sáez 2012) can feel out-dated and out of touch. There are obvious similarities between the different Latin American countries, and some of the biggest problems faced by most of these countries are obviously similar (poverty and violence being the clearest examples), but new breeds of scholars are trying to find new answers. The presumption that if the symptoms are similar the patients need the same medicine is no longer convincing. If nothing else, these books illustrate how different three countries with similar problems (inequality, authoritarian tendencies, poor institutional design, drug-related violence, to name a few) can be. They also illustrate how there is no single solution to the democratic challenges faced by any individual country, let alone a whole continent.

\footnotetext{
${ }^{1}$ It was not long ago that - mainly inspired by the relatively straightforward (at least in comparative terms) cases of the southern European transitions - talk of democratic consolidation dominated the transitional literature. However, as Ana María Bejarano (2011: 6) reminds us, this concept has almost completely disappeared from the literature; this is in great part due to several examples in Latin America where political transitions from authoritarianism have not led to a democratic regime - even if democracy is understood in mere minimalist (shall we say Schumpeterian?) terms. There are any number of adjectives used to qualify the posttransition regimes that emerged in countries such as Mexico, Peru or Argentina (illiberal democracies, nonconsolidated democracies, flawed democracies, hybrid regimes, partly free countries and many others) but, in my opinion, it is Levitsky and Way's concept (2010) of 'competitive authoritarianism' that best describes these regimes - that is, regimes where 'competition is real but unfair'.

2 Broadly speaking, there have been three classic schools that look to explain democratization: (1) modernization theory - which follows the Weberian tradition of capitalist development and has been, to an extent, the approach followed by the US when promoting democracy in Latin America (epitomized by Roosevelt's 'Good Neighbour' policy in the 1930s and Mexico's incorporation into the North American Free Trade Agreemet in 1994); (2) agency- or elite-driven democratization - used widely to explain the successful transitions to democracy in Southern and Eastern Europe (Spain in particular); and (3) institutionalism.

${ }^{3}$ In their seminal work on political culture, first published in 1963, for example, Almond and Verba (1989: 38) confidently claimed that the Mexican Revolution of 1910 had succeeded in stimulating 'modern and democratic aspirations and expectation' in the country and, thus, they considered Mexico to be a democracy.

${ }^{4}$ Venezuela and Colombia are two examples of continuity dominating over discontinuity in politics and culture; the historical parties that emerged after independence survived very much intact until the 1980s in both
} 
countries. Mexico, on the other hand, underwent a complete political transformation following Porfirio Díaz's dictatorship and the Mexican Revolution of 1910 - the Liberal vs. Conservative struggle that dominated the political landscape for over half a century after independence was effectively settled when Díaz took power, while the 1910 revolution completely transformed the socioeconomic structure of the country - yet there has been a clear cultural continuum. In his latest 'reflections' on the burdens implicit in the Mexican national character, former foreign affair minister of Mexico Jorge Castañeda (2011: 13) admits that the arrival of 'modernity' (it is unclear what he means by that) to Mexico is disintegrating, breaking with the previous cultural model, although it has not been replaced by anything else.

${ }^{5}$ Aguayo Quezada (2010: 24) writes that his work is not the place to 'speculate as to the motives for the disdain towards the Mexican political system', thus indicating that there is a time and place to speculate about their motives. The likelier explanation is that Linz et al. - as the rest of the scholarly community, intellectuals, politicians and society in general - were puzzled by the many peculiarities of a regime that, amongst other peculiarities, managed to institutionalize a revolution.

${ }^{6}$ Josep Colomer's Game Theory and the Transition to Democracy (1995) takes the obsession with the paradigmatic nature of the Spanish transition to a whole new level when he explains the process using solely game theory.

${ }^{7}$ In the introduction to a 2009 volume edited by Lawson himself, along with Jorge I. Domínguez and Alejandro Moreno, Chappell Lawson writes: 'a wafer-thin victory of the PAN over the Left was one of the strongest tests of Mexico's new democratic institutions that history could have devised, and these institutions survived. Although the Instituto Federal Electoral (IFE), or Federal Electoral Institute, an autonomous body in charge of administering elections, and the Federal Electoral Court lost some legitimacy as a result of the postelectoral controversy, especially in the eyes of some PRD supporters, most Mexicans continued to hold them in high regard' (Domínguez et al. 2009: 13-14).

Based on the findings present in the same volume, Domínguez explains that: 'Early in this century ... strong majorities of Mexicans believe that the country's political system is democratic. They worry less now about the nature of the political regime and more about serious public issues, such as the lack of public security or the persistence of it' (Domínguez et al. 2009: 299).

8 Arend Lijphart (1971) had already explained how small-N or single-case studies were of paramount importance to comparative politics. That political scientists have almost abandoned single-case studies in favour of statistical analyses is, in the opinion of this author, an unfortunate result of the fixation with causality. Whatever the reason, though, it is clear that, in a general trend in comparative politics towards causality, the term 'sample' is always more appealing than the term 'case study'.

\section{$<$ H1 $>$ REFERENCES $</ \mathrm{h} 1>$}

Acosta, M. (2010), 'The Role of Civil Society', in A. Selee and J. Peschard (eds), Mexico's Democratic Challenges: Politics, Government, and Society (Palo Alto, CA: Stanford University Press).

Ackerman, J.M. (2010), 'The 2006 Elections: Democratization and Social Protest', in A. Selee and J. Peschard (eds), Mexico's Democratic Challenges: Politics, Government, and Society (Palo Alto, CA: Stanford University Press).

Aguayo Quezada, S. (2010), La Vuelta en U: Guía para Entender la Democracia Estancada (Mexico City: Taurus, Santillana Ediciones Generales). Alcántara Sáez, M. (2012), El Oficio del Político (Madrid: Editorial Tecnos).

Almond, G. and Verba, S. (1989), The Civic Culture: Political Attitudes and Democracy in Five Nations, 2nd edn (Thousand Oaks, CA: Sage). 
Bejarano, A.M. (2011), Precarious Democracies: Understanding Regime Stability and Change in Colombia and Venezuela (Notre Dame, IN: University of Notre Dame Press).

Castañeda, J. (2011), Mañana o Pasada: El Misterio de los Mexicanos (Mexico City: Aguilar).

Colomer, J. (1995), Game Theory and the Transition to Democracy: The Spanish Model (Northhampton, MA: Edward Elgar).

Domínguez, J.I., Lawson, C. and Moreno, A. (2009), Consolidating Mexico's Democracy: The 2006 Presidential Campaign in Comparative Perspective (Baltimore, MD: Johns Hopkins University Press).

Edles, L.D. (1995), 'Rethinking Democratic Transitions: A Culturalist Critique and the Spanish Case', Theory and Society, 24(3): 355-84.

Encarnación, O.G. (2001), 'Civil Society and the Consolidation of Democracy in Spain', Political Science Quarterly, 161(1).

Fukuyama, F. (2011), The Origins of Political Order: From Prehuman Times to the French Revolution (London: Profile Books).

Guillén López, T. (2010), 'Federalism and the Reform of Political Power', in A. Selee and J. Peschard (eds), Mexico's Democratic Challenges: Politics, Government, and Society (Palo Alto, CA: Stanford University Press).

Levitsky, S. and Way, L.A. (2010), Competitive Authoritarianism: Hybrid Regimes after the Cold War (New York: Cambridge University Press).

Lijphart, A. (1971) 'Comparative Politics and the Comparative Method', American Political Science Review, 65(3): 682-93.

Merino, M. (2003), La Transición Votada: Crítica a la Interpretación del Cambio Político en México (Mexico City: Fondo de Cultura Económica).

Moore, B. (1966 [1993]), Social Origins of Dictatorship and Democracy: Lord and Peasant in the Making of the Modern World (Boston: Beacon Press).

Moreno, A. (2010), 'Attitudinal Roots?', in A. Selee and J. Peschard (eds), Mexico's Democratic Challenges: Politics, Government, and Society (Palo Alto, CA: Stanford University Press).

Ortega Ortiz, R.Y. (2008), Movilización y Democracia: España y México (Mexico City: El Colegio de México).

Peschard, J. (2010), 'Federal and Local Electoral Institutions: From a National to a Fragmented System', in A. Selee and J. Peschard (eds), Mexico's Democratic 
Challenges: Politics, Government, and Society (Palo Alto, CA: Stanford University Press).

Prud'homme, J.-F. (2010), 'The Restructuring of the Party System in The Wake of the 2006 Elections', in A. Selee and J. Peschard (eds), Mexico's Democratic Challenges: Politics, Government, and Society (Palo Alto, CA: Stanford University Press).

Selee, A. and Peschard, J. (2010) (eds), Mexico's Democratic Challenges: Politics, Government, and Society (Palo Alto, CA: Stanford University Press).

Silva-Herzog Márquez, J. (2010), 'Democratic Antipoetry’, in A. Selee and J. Peschard (eds), Mexico's Democratic Challenges: Politics, Government, and Society (Palo Alto, CA: Stanford University Press).

Tuckman, J. (2012), Mexico: Democracy Interrupted, (London and New York: Yale University Press).

1/9/1990. 'Vargas Llosa: "México es la Dictadura Perfecta"”, EL País, Madrid. 